\title{
Relationship of $\mathrm{CD} 44^{+} \mathrm{CD} 24^{-/ \text {low }}$ breast cancer stem cells and axillary lymph node metastasis
}

\author{
Wei Wei ${ }^{1^{*}}$, Hui Hu${ }^{1}$, Haosheng Tan¹, Louis WC Chow ${ }^{2}$, Adrian YS Yip², Wings TY Loo² \\ From Organisation for Oncology and Translational Research (OOTR) 7th Annual Conference \\ Hong Kong. 13-14 May 2011
}

\begin{abstract}
Background: Axillary node staging plays an important role in the prognostic evaluation and planning of adjuvant treatment. Breast cancer stem cells, identified on the basis of $\mathrm{CD} 44^{+} \mathrm{CD} 24^{-/ 10 w}$ expression, are associated with metastases and drug resistance. It is therefore important to investigate the proportion of $\mathrm{CD} 44^{+} \mathrm{CD} 24^{-/ \text {low }}$ breast cancer stem cells for the diagnosis of metastases in axillary nodes.
\end{abstract}

Methods: Thirty-two ipsilateral axillary lymph nodes were collected from patients diagnosed with invasive breast cancer. Each lymph node (LN) was divided into two equals - one was examined by H\&E staining, while the other was made into a single cell suspension to study the content of $\mathrm{CD} 44^{+} \mathrm{CD} 24^{- \text {llow }}$ cells by flow cytometry (FCM). The relationship was investigated between the content of $\mathrm{CD} 44^{+} \mathrm{CD} 24^{-/ l o w}$ cells and metastases in axillary nodes which were confirmed by histology. Associations were tested using the chi-square test (linear-by-linear association), and the significance level was set at a value of $p<0.05$.

Results: In the 32 axillary nodes, the level of $C D 44^{+} \mathrm{CD} 24^{- \text {llow }}$ cells was determined to be between 0 and 18.4\%: there was no presence of CD44+CD24-/low cells in 9 LNs, of which 2 had confirmed metastasis; there were less than 10\% CD44+CD24-/low cells in 12 LNs, of which 6 had confirmed metastasis; and there were more than 10\% CD44+CD24-/ low cells in $11 \mathrm{LNs}$, of which 9 had confirmed metastasis. A higher percentage of detected $\mathrm{CD} 44^{+} \mathrm{CD} 24^{- \text {-low }}$ cells was significantly associated with more confirmed LN metastases $(p=0.009)$.

Conclusions: $\mathrm{CD} 44^{+} \mathrm{CD} 24^{- \text {-low }}$ breast cancer stem cells might help clinicians to determine the presence of LN metastases. However, its prognostic value remains unclear, while histological diagnosis is still the gold standard.

\section{Background}

Breast cancer stem cells (BCSCs) represent a minor subset of cells in a breast tumor that is deemed as the driver of tumor initiation, displaying resistance to drugs and developing metastatic disease [1]. BCSCs, identified on the basis of $\mathrm{CD} 44^{+} \mathrm{CD} 24^{- \text {low }}$, Lin expression, could form tumors in nonobese, diabetic/severe combined immunodeficiency disease mice with as few as 200 of such cells [2]. The expression was strongly associated with poor clinical outcome and other prognostic indicators such as tumor histological grade, proliferation index, hormonal receptor expressions, and avian erythroblastosis oncogene B2 overexpression [3].

\footnotetext{
*Correspondence: rxwei1123@163.com

'Department of Breast Surgery, Peking University Shenzhen Hospital,

Shenzhen, Guangdong, China

Full list of author information is available at the end of the article
}

A high percentage of BCSCs enriched with $\mathrm{CD} 44^{+} \mathrm{CD} 24^{-1}$ ${ }^{\text {low }}$ phenotype was found harbored in basal-like tumors [4] and the phenotype was observed in 'triple-negative' breast cancer that responded poorly to chemotherapy [5]. The combined expressions with CD44 associated with stem cell-like characteristics and CD24 related to differentiated epithelial features [6] as prognostic markers for breast cancer however remains controversial.

Positive locoregional LN has long been recognized as an indicator of regional metastases and, subsequently, a reservoir for further lymphatic and later visceral metastases [7-9]. It is well noted that tumor cells with $\mathrm{CD} 44^{+} \mathrm{CD} 24^{-/ \text {low }}$ expression not only possess malignant behavior as other tumor cells, but also share with normal stem cells the capacity for self-renewal [3,10-12].
Ciomed Central

() 2012 Wei et al; licensee BioMed Central Ltd. This is an Open Access article distributed under the terms of the Creative Commons Attribution License (http://creativecommons.org/licenses/by/2.0), which permits unrestricted use, distribution, and reproduction in any medium, provided the original work is properly cited. 
In a recent in vitro and in vivo study, a high proportion of BCSCs with $\mathrm{CD} 44^{+} \mathrm{CD} 24^{-/ \text {low }}$ expression was presented in a model with high lymphatic metastatic ability [13]. The expression level of BCSCs might highlight the metastatic potential of the disease in the lymphatic system, the major route of breast cancer metastases.

Regional LN dissection has been regarded as a staging procedure rather than surgical treatment because it was not seen to benefit survival. $[14,15]$. The sentinel lymph node (SLN) biopsy has modified the need of axillary surgery in the treatment of breast cancer for patients; yet, it remains a staging procedure but reduces post-operative morbidity [16]. Accurate staging of ipsilateral LN involvement is, however, the best clinicopathologic prognostic indictor for oncologists to precisely evaluate and offer breast cancer patients the most suitable adjuvant therapy. Hematoxylin and eosin (H\&E) staining of the surgical LN samples is still the current gold standard for diagnosing axillary LN metastasis. However, the process of creating paraffin-embedded slides involves many steps, leading to a prolonged wait for pathological results. In this study, we aimed to investigate the proportion of $\mathrm{CD} 44^{+} \mathrm{CD} 24^{-/ \text {low }}$ BCSCs in axillary $\mathrm{LN}$ and examined the relationship with $\mathrm{H} \& \mathrm{E}$ staining results.

\section{Methods}

\section{Patients}

The study was approved by the local ethics committee of the Peking University Shenzhen Hospital. Between April 2008 and April 2009, a total of 32 cases were prospectively sampled for ipsilateral axillary LNs at the Department of Breast Surgery of Peking University Shenzhen Hospital. All patients were diagnosed with invasive breast cancer, confirmed by histological assessment and were scheduled for surgery. Women who previously received chemotherapy or endocrine therapy for breast cancer were excluded from the trial. The median age of female patients enrolled into the trial was 42 years (range, 21-69 years).

\section{Antibodies and materials}

Mouse-anti-human IgG1-FITC (No. : 11-4714), IgG2bPE-CY5 (No. : 15-4031), CD24-FITC (No. : eBioSN3), CD44-PE-CY5 (No. : IM7), and CD326-PE (No. : 1B7) were obtained from eBioscience, USA; collagenase III, fetal bovine serum, and OptilyseC hemolytic agents were obtained from GIBICO, USA. Flow cytometry: Epics XL, Beckman Coulter were used.

\section{Preparation of single cell suspension}

The entire ipsilateral axillary LNs - swollen and hard in texture - were obtained from patients after surgical resection within one hour. Each node was divided into two equal parts. One was taken for histopathological examination employing H\&E staining, and the other was prepared for a single cell suspension. Adipose tissue of the LN was removed using ophthalmic scissors, and the specimen was washed repeatedly using phosphate buffer solution (PBS) until the blood was totally removed. The washed specimen was then placed in a Petri dish which was put on ice, fixed by ophthalmic scissors, repeatedly pricked using No. 9 syringe needles and rinsed with small amounts of PBS until the sample turned filamentous. After, the specimen was repeatedly stamped using two tissue forceps and rinsed with small amounts of PBS. The washing liquid was collected and centrifuged at $1500 \mathrm{r} /$ min for five minutes. The supernatant was removed and one $\mathrm{ml}$ of PBS was added for re-hanging. Afterward, 3 $5 \mathrm{ml}$ of $0.1 \%$ collagenase III was added, and the sample was placed into a $37{ }^{\circ} \mathrm{C}$ water bath for 10-30 minutes, during which the sample was pipetted once every 5 minutes using a $10 \mathrm{ml}$ pipette. Fetal bovine serum (FBS) was then added to a final concentration of $10 \%$ and centrifuged at $1500 \mathrm{r} / \mathrm{min}$ for 5 minutes. Supernatant was removed and $2 \mathrm{ml}$ PBS was added for re-suspension, and then filtered through 300-mesh stainless steel sieve. The filtered fluid was added with $0.75 \mathrm{ml}$ OptilyseC and left to stand for 15 minutes. Supernatant was removed after the fluid was added and centrifuged at $1500 \mathrm{r} / \mathrm{min}$ for $5 \mathrm{~min}-$ utes; afterward, PBS was added for cleaning purposes. Finally, 100ul PBS was added for re-suspension.

\section{Cell mark and flow cytometry test}

Antibodies IgG1-FITC 10ul, CD326-PE 10ul, IgG2b-PECY5 10ul and cell suspension 50ul were added into control EP tubes, while antibodies CD24-FITC 10ul, CD326-PE 10ul, CD44-PE-CY5 10ul and cell suspension $50 u$ were added into target EP tubes. The tubes were incubated at room temperature for 15 minutes in the shade. Afterward, the tubes were washed with PBS and 500ul PBS was added for re-suspension. The voltage of the control was reset with CD326-PE/SSC to detect the proportion of CD $44^{+} \mathrm{CD} 24^{-/ \text {low }}$ cells in CD326-positive cell populations.

\section{Statistical analysis}

Chi-square test (linear-by-linear association) was used to examine the relationship between $\mathrm{CD} 44^{+} \mathrm{CD} 24^{-/ \text {low }}$ cell contents and the axillary LN metastasis using SPSS for windows release 13.0 (SPSS Inc., USA). The significance level was set for p-value less than 0.05 .

\section{Results}

The mechanical-enzymatic method was employed to make 32 fresh LN tissue samples into a single cell suspension. The $\mathrm{CD} 44^{+} \mathrm{CD} 24^{-/ \text {low }}$ cell content was detected using flow cytometry and compared with $\mathrm{H} \& \mathrm{E}$ staining of paraffin section. In $9 \mathrm{LNs}$ in which $\mathrm{CD} 44^{+} \mathrm{CD} 24^{-/ \text {low }}$ 
cell content was $0 \%, 2$ were confirmed with metastasis. In $12 \mathrm{LNs}$ where $\mathrm{CD} 44^{+} \mathrm{CD} 24^{-/ \text {low }}$ cell content was between $0 \%$ and $10 / \%, 6$ were confirmed with metastasis. In $11 \mathrm{LNs}$ in which $\mathrm{CD} 44^{+} \mathrm{CD} 24^{-/ \text {low }}$ cell content was between $10 \%$ and $18.4 \%$, 9 were confirmed with metastasis (Table 1 and figure 1). It can therefore be concluded that a higher percentage of CD $44^{+} \mathrm{CD} 24^{-/ \text {low }}$ cells detected in axillary LN was significantly associated with a higher chance of LN metastasis $(p=0.009)$.

\section{Discussion}

Cancer stem cell is an ancient but everlasting topic, where hypotheses about cancer stem cells existed as early as 100 years ago [17-19] and the discovery of leukemia stem cells has suggested distinct cell subpopulations [20]. In 1997, Bonnet et al. isolated CD34CD38 cells in human acute myeloid leukemia [20]. In recent years, scientists were able to isolate stem-like cells (tumor initiating cells) from solid tumors. These findings not only laid the theoretical foundation of cancer stem cells, but also shed light for the treatment of malignant tumor. For a long time, treatment strategies for malignancy were mainly aimed at tumor cells in the proliferation and mitotic phases. This leads cancer cells into interphase, the main cause of cancer recurrence and metastasis. Cancer stem cell theory has changed the traditional treatment strategy for patients and will one day completely cure malignant tumors [21].

As researchers are able to isolate $\mathrm{ESA}^{+} \mathrm{CD} 44^{+} \mathrm{CD} 24^{-/ \text {low }}$ $\mathrm{LIN}^{-}$cells from breast cancer tissues [3], more and more studies on BCSCs have appeared, particularly on CD $44^{+}$ CD24 ${ }^{-/ \text {low }}$ cell's clinical correlation. However, there is little research about its clinical value. The mechanical-enzymatic method was employed to transform 33 fresh LN tissue samples into a single cell suspension, the CD $44^{+}$ $\mathrm{CD} 24^{-/ \text {low }}$ cell content was then detected using flow cytometry and compared with $H \& E$ stained paraffin section to explore the relationship between $\mathrm{CD} 44^{+} \mathrm{CD} 24^{-/ \text {low }}$ cell content and LN metastasis.

\section{Process of breast cancer metastasis to axillary LNs}

Invasive breast cancer cells first invade lymphatic vessels and then travel to local LNs through the lymphatic flow system. The first involved nodes are one or a few pectoral LNs, known as SLN. In the LNs, cancer cells first cluster in marginal sinus, then accumulate in the entire LN. This causes LNs to swell and harden, appearing gray in sections. Sometimes, tumor tissues invade capsules and cause several LNs to merge together. After regional LN metastasize, tumor cells continue to transfer to the next nodes, eventually entering the blood vessel through the thoracic duct and secondary metastasis might occur [22].

Contamination of blood cells, cell debris and other particles in a single cell suspension may cause nonspecific bindings and influence the result. They may be wrongly labeled by fluorescent monoclonal antibodies, resulting in non-specific binding and thus inducing experimental errors. ESA (CD326), also known as epithelial-specific antigen (EpCAM), is cell surface glycoprotein of $40 \mathrm{Kda}$ in weight. It's a broad spectrum marker of epithelial cells [23]. In our study, we employed CD326 (ESA) / SS instead of FS / SS as a means of determining ESA-positive cells and to decrease the influence of cell debris and blood cells. After the detection scheme was established, we tested the scheme using breast cancer cell lines and determined the preliminary parameters to minimize experimental errors. In our study, the specificity of epithelial cell marker CD326 was about $80 \%$. Normal lymphoid tissue may still contain a small amount of other endothelial cells after processing; therefore, false positive results may still arise during the measurement of CD $44^{+} \mathrm{CD} 24^{-/ \text {low }}$ cell contents when representing the proportion of BCSCs in axillary LN metastasis. A low proportion of breast cancer cells present in LNs may also result in the absence of specific binding with CD326 monoclonal antibody and in turn, the accuracy of detecting $\mathrm{CD} 44^{+} \mathrm{CD} 24^{-/ \text {low }}$ cell contents in SLN was reduced.

\section{Relationship of CD44+CD24-/low cell content and axillary LN metastasis}

In 2005, Abraham BK et al. confirmed the proportion of $\mathrm{CD} 44^{+} \mathrm{CD} 24^{-/ \text {low }}$ cells was associated with distant metastasis using immunohistochemical staining [24]. In 2008, Ling LJ et al. confirmed that a tumor having a higher proportion of $\mathrm{CD} 44^{+} \mathrm{CD} 24^{-/ \text {low }}$ cells is more prone to bone metastasis using animal models [25]. It was therefore postulated that the content of $\mathrm{CD} 44^{+} \mathrm{CD} 24^{-/ \text {low }}$ cells or, in other words, the proportion of BCSCs might be related to tumor aggressiveness and distant metastasis, but the relationship with axillary LN status was not well established. It is possibly because lymphatic circulation is slower and

Table 1 Comparison of $\mathrm{CD} 44^{+} \mathrm{CD} 24^{-/ \text {low }}$ cell content and axillary LNs metastases confirmed by H\&E staining from 32 cases

\begin{tabular}{cccc}
\hline $\begin{array}{c}\text { CD44 }{ }^{+} \mathrm{CD} 24^{-/ \text {low }} \text { cell content } \\
(\%)\end{array}$ & $\begin{array}{c}\text { Number of axillary lymph } \\
\text { nodes }\end{array}$ & $\begin{array}{c}\text { Metastases confirmed in paraffin } \\
\text { sections }\end{array}$ & $\begin{array}{c}\text { Percentage of positive axillary lymph node } \\
(\%)\end{array}$ \\
\hline 0 & 9 & 2 & 22.2 \\
\hline $0 i 1 / 2 z ̌ 10$ & 12 & 9 & 50.0 \\
\hline $10 i 1 / 2 z ̌ 18.4$ & 11 & 81.8 \\
\hline
\end{tabular}




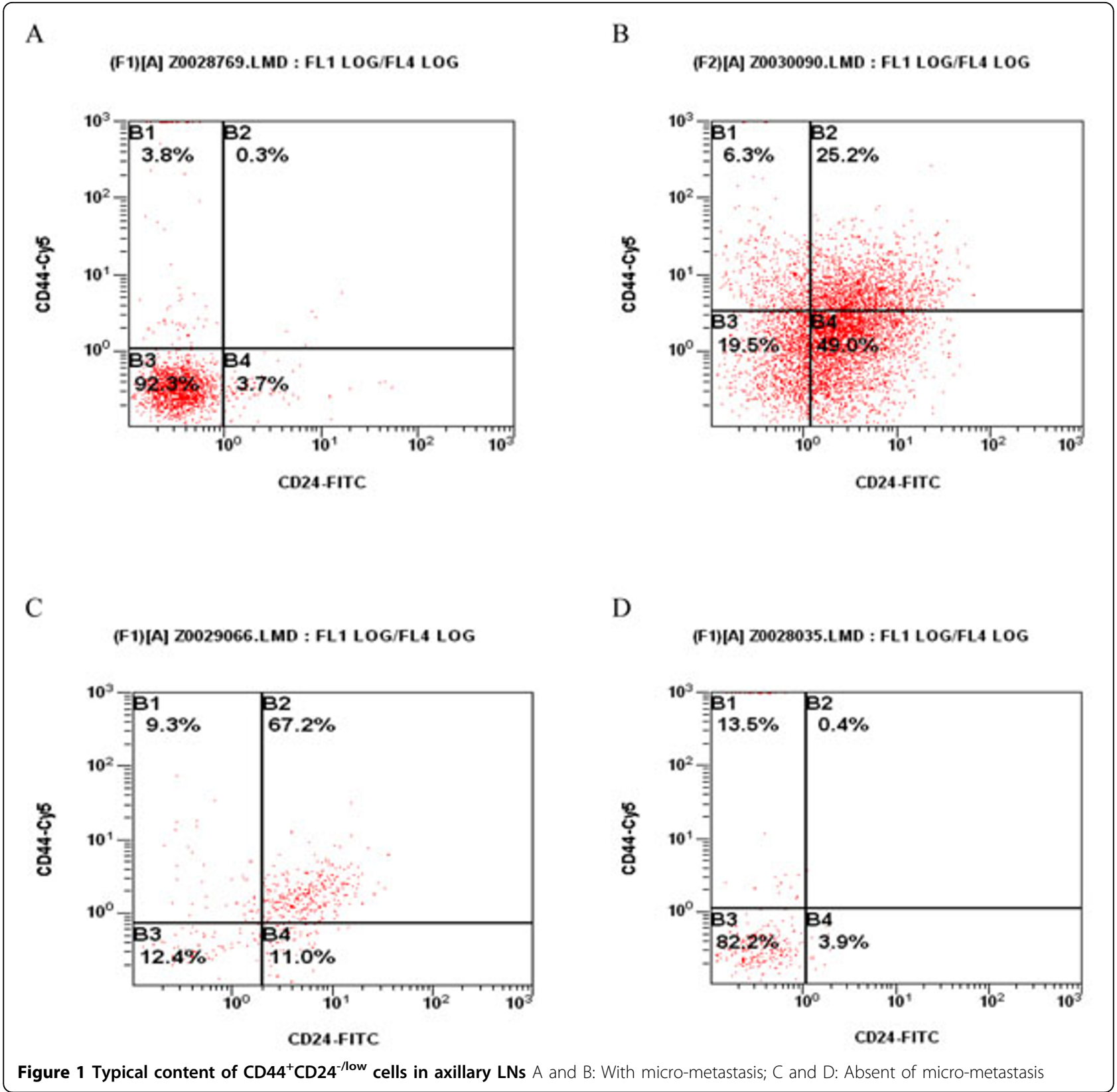

shorter than blood circulation and, in addition to invasive stem cells, non-stem cells can also metastasize to ipsilateral axillary LNs. Compared to stem cells, non-stem cells have a smaller chance of metastasizing according to their weaker degree of aggressiveness. It was speculated that distant metastasis of breast cancer is mainly caused by stem cells.

\section{Diagnosis value of CD44+CD24-/low cells in axillary LN metastases}

Currently, common LN micro-metastasis markers of breast cancer are human mammaglobin (hMAM) and adhesion protein 1, where hMAM is known to have high specificity and sensitivity. Marchetti A et al.[26] detected LNs using the real-time polymerase chain reaction (RTPCR) laboratory technique, and only hMAM and CEA mRNA were not detected in LNs of healthy individuals, therefore concluding that the above two markers have high specificity. Mitas M et al. [27] demonstrated that hMAM was over-expressed in 16/17 pathology-negative LNs, suggesting that it could be used as marker of breast cancer micrometastases in LNs. Mucin, a Mucin 1 mRNA encoding product, is a membrane glycoprotein with transmembrane domain. Mucin 1 has become an indicator of LN micrometastasis in breast cancer patients. Hao XB et al. [28] found that mucin 1 mRNA was expressed in the 
LNs of all 86 breast cancer patients and RT-PCR did not show mucin 1 expression in LNs with benign disease. However, results are inconsistent. Marchetti A et al. [26] detected the expression of mucin 1 mRNA in healthy LNs, but with low specificity. These two indicators for LN metastasis of breast cancer markers may only relate to the distribution of organs, while CD $44^{+} \mathrm{CD} 24^{-/ \text {low }}$ cells not only relate to the distribution of organs, but also to their biological characteristics (invasiveness). Compared with hMAM and mucin $1, \mathrm{CD} 44^{+} \mathrm{CD} 24^{-/ \text {low }}$-expressing BCSCs may have higher false negative and lower false positive results.

\section{Conclusions}

In conclusion, this study suggests that in using $\mathrm{CD} 44^{+}$ CD24 ${ }^{-/ \text {low }}$ cells to estimate the metastasis of axillary LNs, a higher content corresponds to lower false-positive results. As $\mathrm{CD} 44^{+} \mathrm{CD} 24^{-/ \text {low }}$ double-labeling LN metastases in cell distribution and function, it may have lower false positive rates compared to existing markers. Further investigation on the relationship between the $\mathrm{CD} 44^{+} \mathrm{CD} 24^{-/ \text {low }}$ expression of tumor cells and LN metastases is warranted. The detection of BCSCs in LNs may be useful in predicting micrometastases, especially in sentinel LNs, as a routine supplementary pathological reference.

\section{Acknowledgements}

Editorial assistance was provided by Elizabeth L.Y. Ng, an employee of Organisation for Oncology and Translational Research, Hong Kong. This article has been published as part of Journal of Translational Medicine Volume 10 Supplement 1, 2012: Selected articles from the Organisation for Oncology and Translational Research (OOTR) 7th Annual Conference. The ful contents of the supplement are available online at http://www.translationalmedicine.com/supplements/10/S1.

\section{Author details}

${ }^{1}$ Department of Breast Surgery, Peking University Shenzhen Hospital, Shenzhen, Guangdong, China. ${ }^{2}$ Organisation for Oncology and Translational Research and UNIMED Medical Institute, Hong Kong, China.

\section{Authors' contributions}

WW conducted the study. AY participated in manuscript writing. WL performed data analysis and participated in writing. $\mathrm{HH}$ conducted the study. HT conducted the study. LC performed data analysis.

\section{Competing interests}

The authors declare that they have no competing interests.

Published: 19 September 2012

\section{References}

1. Morrison BJ, Schmidt CW, Lakhani SR, Reynolds BA, Lopez JA: Breast cancer stem cells: implications for therapy of breast cancer. Breast Cancer Res 2008, 10:210.

2. Vaillant F, Asselin-Labat ML, Shackleton M, Lindeman GJ, Visvader JE: The emerging picture of the mouse mammary stem cell. Stem Cell Rev 2007, 3:114-23.

3. Al-Haij M, Wicha MS, Benito-Hernandez A, Morrison SJ, Clarke MF: Prospective identification of tumorigenic breast cancer cells. Proc Natl Acad Sci U S A 2003, 100:3983-8.

4. Ricardo S, Vieira AF, Gerhard R, Leitao D, Pinto R, Cameselle-Teijeiro JF, Milanezi F, Schmitt F, Paredes J: Breast cancer stem cell markers CD44,
CD24 and ALDH1: expression distribution within intrinsic molecular subtype. J Clin Pathol

5. Giatromanolaki A, Sivridis E, Fiska A, Koukourakis MI: The CD44+/CD24phenotype relates to 'triple-negative' state and unfavorable prognosis in breast cancer patients. Med Oncol 2011, 28:745-52.

6. Park SY, Lee HE, Li H, Shipitsin M, Gelman R, Polyak K: Heterogeneity for stem cell-related markers according to tumor subtype and histologic stage in breast cancer. Clin Cancer Res 2010, 16:876-87.

7. Ward PM, Weiss $L$ : The relationship between lymphogenous and hematogenous metastasis in rats bearing the MT-100-TC mammary carcinoma. Clin Exp Metastasis 1989, 7:253-64.

8. Ward PM, Weiss L: Metachronous seeding of lymph node metastases in rats bearing the MT-100-TC mammary carcinoma: the effect of elective lymph node dissection. Breast Cancer Res Treat 1989, 14:315-20.

9. Sleeman JP: The lymph node as a bridgehead in the metastatic dissemination of tumors. Recent Results Cancer Res 2000, 157:55-81.

10. Sheridan C, Kishimoto H, Fuchs RK, Mehrotra S, Bhat-Nakshatri P, Turner CH, Goulet R Jr, Badve S, Nakshatri H: CD44+/CD24- breast cancer cells exhibit enhanced invasive properties: an early step necessary for metastasis. Breast Cancer Res 2006, 8:R59.

11. Ginestier C, Korkaya H, Dontu G, Birnbaum D, Wicha MS, Charafe-Jauffret E: The cancer stem cell: the breast cancer driver. Med Sci (Paris) 2007, 23:1133-9

12. Wright MH, Calcagno AM, Salcido CD, Carlson MD, Ambudkar SV, Varticovski L: Brca1 breast tumors contain distinct CD44+/CD24- and CD133+ cells with cancer stem cell characteristics. Breast Cancer Res 2008, 10(1):R10.

13. Pandit TS, Kennette W, Mackenzie L, Zhang G, Al-Katib W, Andrews J, Vantyghem SA, Ormond DG, Allan AL, Rodenhiser DI, Chambers AF, Tuck AB: Lymphatic metastasis of breast cancer cells is associated with differential gene expression profiles that predict cancer stem cell-like properties and the ability to survive, establish and grow in a foreign environment. Int J Oncol 2009, 35:297-308.

14. Rosen PP: Rosen's Breast Pathology. Philadelphia: Lippincott Williams \& Wilkins; , 2nd 2001, 345

15. Fisher B, Jeong JH, Anderson S, Bryant J, Fisher ER, Wolmark N: Twentyfive-year follow-up of a randomized trial comparing radical mastectomy, total mastectomy, and total mastectomy followed by irradiation. $N$ Engl $\lrcorner$ Med 2002, 347:567-75.

16. Veronesi U, Paganelli G, Viale G, Luini A, Zurrida S, Galimberti V, Intra M, Veronesi P, Maisonneuve P, Gatti G, Mazzarol G, De Cicco C, Manfredi G, Fernandez JR: Sentinel-lymph-node biopsy as a staging procedure in breast cancer: update of a randomised controlled study. Lancet Oncol 2006, 7:983-90.

17. Sell S: Stem cell origin of cancer and differentiation therapy. Crit Rev Oncol Hematol 2004, 51:1-28.

18. Durante F: Nesso fisio-pathologico tra la struttura dei nei materni e la genesi di alcuni tumori maligni. Arch Memor Observ Chir Pract 1874, 11:217-26.

19. Cohnheim J: Ueber entzundung und eiterung. Path Anat Physiol Klin Med 1867, 40:1-79.

20. Bonnet D, Dick JE: Human acute myeloid leukemia is organized as a hierarchy that originates from a primitive hematopoietic cell. Nat Med 1997, 3:730-7.

21. Wicha MS, Liu S, Dontu G: Cancer stem cells: an old idea-a paradigm shift. Cancer Res 2006, 66:1883-90.

22. Ran S, Volk L, Hall K, Flister MJ: Lymphangiogenesis and lymphatic metastasis in breast cancer. Pathophysiology 2010, 17:229-51.

23. Baeuerle PA, Gires O: EpCAM (CD326) finding its role in cancer. $\mathrm{Br} J$ Cancer 2007, 96:417-23.

24. Abraham BK, Fritz P, McClellan M, Hauptvogel P, Athelogou M, Brauch H: Prevalence of CD44+/CD24-/low cells in breast cancer may not be associated with clinical outcome but may favor distant metastasis. Clin Cancer Res 2005, 11:1154-9.

25. Ling $L$, Wang $S$, Liu XA, Shen EC, Ding Q, Lu C, Xu J, Cao QH, Zhu HO Wang F: A novel mouse model of human breast cancer stem-like cells with high CD44+CD24-/lower phenotype metastasis to human bone. Chin Med J (Engl) 2008, 121:1980-6.

26. Marchetti A, Buttitta F, Bertacca G, Zavaglia K, Bevilacqua G, Angelucci $D$, Viacava P, Naccarato A, Bonadio A, Barassi F, Felicioni L, Salvatore S, Mucilli F: mRNA markers of breast cancer nodal metastases: comparison 
between mammaglobin and carcinoembryonic antigen in 248 patients. J Pathol 2001, 195:186-90.

27. Marchetti A, Buttitta F, Bertacca G, Zavaglia K, Bevilacqua G, Angelucci D,

Viacava P, Naccarato A, Bonadio A, Barassi F, Felicioni L, Salvatore S,

Mucilli F: mRNA markers of breast cancer nodal metastases: comparison between mammaglobin and carcinoembryonic antigen in 248 patients. J Pathol 2001, 195:186-90.

28. Hao XB, Fu J, Qiu FH: Clinical significance of RT-PCR in detection of axillary lymph node micrometastases from breast cancer. Ai Zheng 2003, 22:964-7.

doi:10.1186/1479-5876-10-S1-S6

Cite this article as: Wei et al:: Relationship of $\mathrm{CD} 44^{+} \mathrm{CD} 24^{- \text {-low }}$ breast cancer stem cells and axillary lymph node metastasis. Journal of

Translational Medicine 2012 10(Suppl 1):S6.

Submit your next manuscript to BioMed Central and take full advantage of:

- Convenient online submission

- Thorough peer review

- No space constraints or color figure charges

- Immediate publication on acceptance

- Inclusion in PubMed, CAS, Scopus and Google Scholar

- Research which is freely available for redistribution

Submit your manuscript at www.biomedcentral.com/submit

C) Biomed Central 